\title{
Drowning the Fear that Floats Liam Richards
}

'Dude, WhaT'RE YOU doing?' It's my brother.

I raise my eyebrow in confusion. 'Washing my hands?'

'Yeah, but didn't you do that already?'

'So?'

'So why are you doing it again?'

'I'm not ...' I avoid his gaze. I can feel a cloud of judgement forming above me, waiting to pour down on my head at any second in a torrent of contemptuous rain.

'Yeah, that just raises more questions than it answers.'

I feel the first drops hit my head. 'I mean, I'm not doing it again.' My scrubbing intensifies.

'So, what? You've been here the whole time? You never left?' His derision seems obvious at this point.

'No. I never left. Yes, I'm still washing my hands. Yes, I know it's pointless and that it's illogical. I don't care. I'm gonna do it anyway.' I'm soaked and there's a puddle at my feet, the sheer criticism amounting to more than the cloud could contain. 'Now bugger off, yeah?'

'You're an idiot.' My brother turns and leaves the bathroom. The storm follows him.

I turn my attention to the spotless sink; its pristine surface completely devoid of any foreign substance. I find myself staring into the slick tap above it. My distorted reflection stares back; its eyes enlarged and eerily focused on mine, as if it were staring down a well directly into my soul. Cool water gushes from its mouth, engulfing my hands in a soapy layer of liquid cleanliness. It's an isolated storm, forming my 
own personal moat; protecting against the armies of germs seeking to conquer the untainted lands that are my hands.

Such a concept is completely ridiculous, when I actually think about it. He's right, my brother. I know my hands get no cleaner, no matter how many I times I repeat the process: pump twice for soap, lather then rinse the foam, repeat. But I do it anyway. As surely as a puddle forms in the rain, I'll repeat my hand washing ritual an unreasonable number of times. It settles the tugging at the back of my skull and which continues into the palms of my hands; an imaginary feeling of filthiness. The quiet paranoia just barely drowning out the chorus of reason that I know is what I should actually be listening to.

My hands still submerged, I look up. The large mirror above the sink is spotless. It would not do it justice to say it's like staring through a window; the reflection is too perfect for that. It reveals just how clean my mum keeps the bathroom. Not a corner of the room could escape its view and it all looks as perfect in the mirror as it does through my own eyes. However, the room is not perfect; three teenagers had used this bathroom in the last half a day, and yet it is my hands which are unclean. It is my hands, which are being flooded by enough water to bring even Noah to despair, that are what I consider to be sullied.

The bathroom now reeks of soap. Continuing to scrub my hands, I drift my attention to my reflection. I'm the kind of person who appreciates logic. Science and math are what I excel at. I know for a fact that my hands stopped getting cleaner around the third cycle. So for what possible reason do I insist on continuing to drown my hands? The water is both cleansing and corrupting. It's an uncomfortable paradox. It allows me to float but if I'm not careful, it'll just as happily drag me under and drown me without so much as a second thought. It's not even sentient. How can it have a second thought? It doesn't have a first thought. It's a tool; a dangerous tool. It's stupid. I'm stupid. How can someone my age be so pathologically terrified of imaginary microbes?

My brother's contempt has spilled over and onto me. Storm clouds are forming above my head.

'Stop,' I'm speaking only to myself. The room is warm but it may as well be the Arctic. My fear has made me numb.

I say it again, 'Stop.'

I close my eyes and take a deep breath. I exhale slowly and repeat the process. Opening my eyes and avoiding the ocean of self-loathing 
forming in the mirror, I move my gaze towards the taps. Using only the very tips of my index finger and thumb, I turn the tap until the torrential downpour slows to a stop. Careful to avoid touching anything, I shake the remaining contempt from my fingers. I was letting the paranoia take control. I know this. I wasn't always like this before; I won't be in the future. As long as I don't let the fear float, it will drown.

The clouds begin to dissipate.

The ocean recedes.

A wave of calm flows over me; having replaced my fear with reason, I'm ready to continue my day.

I take a step back, and turn towards the towel rack.

I see the towel.

It's filthy.

I sigh.

'Fuck.' 